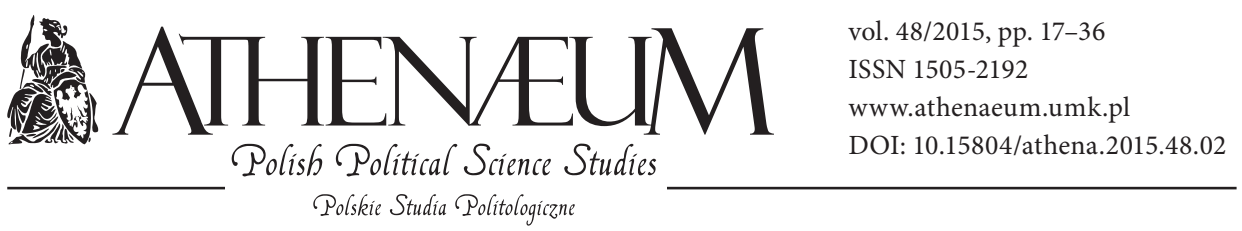

\title{
THE ENEMY STEREOTYPE \\ IN THE POLITICAL ACTIVITY - THEORETICAL REFLECTIONS
}

\author{
Sabina Olszyk*
}

\begin{abstract}
The concept of the enemy stereotype, which is permanently present in colloquial, journalistic, and academic discussions, has not been scientifically analysed so far. In this article, an attempt to provide a definition of "the enemy stereotype" as an independent linguistic being has been made. The stages of this term taking shape in the political reality have also been presented. The article has strictly theoretical nature, and is based on scientific achievements in the fields of research related to stereotypes and hostility. In the author's opinion, the analysis of the phenomenon of stereotyping carried out from a sociological, psychological, and linguistic point of view is necessary. A reflection on the issue of hostility in general, and on the image of the enemy in political activities in particular is also fundamental.
\end{abstract}

\section{- KEYWORDS}

enemy stereotype, enemy, stereotype, stereotyping

The concept of the "enemy stereotype", so often used in a colloquial language, has not yet been a subject of scientific research and precise definition. It is probably caused by the fact that the concepts of "stereotype" and "enemy" for many years have been functioning separately. The "enemy stereotype" as a separate term started gaining popularity with the dissemination of research about the hostility phenomenon in totalitarian and communist systems, when

* Pedagogical University of Cracow, Institute of Political Science. 
concepts such as "the objective enemy", "the enemy of the class", and "the enemy of the people" arose (Arendt 2008; Karolczuk 2010; Jakubowska-Branicka 2008). It was noticed then that the picture of the enemy, its image in the society, resulting frequently from tradition and socialization processes as well as being an effect of propaganda controlled by the authority, is associated with phenomenon of stereotyping. Therefore, a concept of "enemy" was more and more often merged with the term "stereotype", thus creating a separate term: "the enemy stereotype", which began to function commonly as an independent linguistic existence and it quickly found its way to press, political, and scientific rhetoric.

In an enemy stereotyping context, two research areas are important. One of them regards the stereotype issue. There is a rich, professional, foreign-language literature on this subject, primarily in English (Lippmann 1922; Dovidio, Gaertner 1986; Bar-Tal et al. 1989; Fiske, Taylor 1991; Stangor 2000; Bar-Tal, Teichman 2005; Wang 2006). Also in Poland, research on stereotypes was carried out, which resulted in the creation of a sequence of valuable studies. They reviewed the problem from different points of view, such as psychological, sociological, linguistic, or cultural one. It is sufficient to mention works of Adam Schaff (1981), Jerzy Bartmiński (1985), Ida Kurcz and Zdzisław Chlewiński (1992, 1994), Dominika Maison (1997), Mirosław Kofta and Aleksandra Jasińska-Kania (2001), and many others. However, political science and sociological literature dealing with stereotypes is mostly devoted to sexual, racial, or ethnic stereotypes. Little attention is given to political stereotypes, although contemporary propaganda measures increasingly use them. The second research area is connected with "an enemy" issues and includes quite a rich collection of scientific publications on this subject. Noteworthy are works authored by: Hannah Arendt (2008), Michał Głowiński (1993), Iwona Jakubowska-Branicka (2008), Edward Karolczuk (2010). It is necessary to point out that these works largely analyze the issue of the "enemy" in the totalitarian propaganda. Various research within different fields of study on stereotyping the rival, opponent, or enemy focused first of all on a psychological and sociological analysis of the stereotype of "other" and "own". An example of this can be found in the works of Andrzej Mirga (1984) or Jacek Sobczak (2005). Therefore, studies which would merge the above-mentioned areas of research and precisely define the term of the "enemy stereotype", showing its functioning in political reality stereotype, are missing. These deliberations are an attempt to fill this gap. 


\section{STEREOTYPE PROBLEMS IN THE STUDY OF DIFFERENT DISCIPLINES}

Walter Lippmann already noticed that social awareness is on one side the stereotypes of public opinion, and on the other side the visions imposed by propaganda. The use of stereotypes in the political and social life, leading to the suspension of criticism, the exemption from thinking through expressive classification and evaluation of phenomena as well as hampering an objective assessment of events carried out by the recipient (Gostkowski 1959: 39-84), became an excellent tool to influence the society. Stereotyping constitutes, in fact, a subtle way to eliminate the enemy, camouflaging genuine intentions, because it enables to create the enemy's image in a way which discourages declared and potential supporters (Reber 2000: 708). Stereotype, through its social, black and white, and emotional nature is a handy simplification of the overview of reality: it makes it easier to describe briefly the events of which the man is a witness or about which he is informed (Jeziński 2007: 198).

Many definitions of a stereotype, created by researchers from different scientific fields, were included in the subject literature. It is widely assumed that the stereotype constitutes a collection of individuals' or social groups' beliefs about the characteristics of other individuals, groups of people, or social facts (Nelson 2003: 27). In addition, a group of permanent elements characterizing a stereotype is indicated: it is an evaluative judgement, it has an emotional tone, it is relatively durable, inflexible, and not always in accordance with the actual state of affairs to which it refers. A stereotype most often assumes a form of related judgements and behaviours which are present in the awareness of a specific social group (Sasińska-Klas 2010: 10).

\section{THE STEREOTYPE IN THE SOCIOLOGICAL APPROACH}

In sociology, the issue of a stereotype, and mainly all its possible dangerous consequences, was brought up by an outstanding Polish sociologist Piotr Sztompka (2002: 300). He treated a stereotype as a pathological symptom in social awareness and emphasized that the stereotype is a simplified, unilateral, extremely exaggerated image of certain community, which treats all its members in an undifferentiated way, irrespective of their individual qualities. He claimed 
that a stereotype was most often created on the basis of individual experience with representatives of communities, which are then generalized and in an unauthorized way transferred to regard the entire community. According to P. Sztompka, a positive and negative stereotypes may be present in the society, and while the first ones do not raise objection of groups which they concern, negative stereotypes constitute a real danger as they may lead to discrimination, if not elimination of stereotyped groups from social life. Using "the scale of public rejection", P. Sztompka depicted how stereotypes may become a cause of persecution and even the extermination of a social group. He pointed out the particular danger of stereotypes in case when they result in clearly negative evaluations of the described group, as well as when such negative characteristics are treated as irremovable, because they are associated with a very nature of the group, independent of individual efforts of its members. Negative stereotypes of this kind become superstitions, which complemented with an additional element, i.e. emotions of resentment and hostility towards others, may lead to the separation of these groups and the enlargement of social distance, and finally even to total segregation, i.e. customary or legally guaranteed isolation. This is followed by signs of worse treatment of the members of other groups, the reduction of chances to access education, profession, political rights and other valued goods, only because somebody is a member of a group subjected to superstition. Such an action is known as discrimination. The next stage which may appear as a result of stereotypes is a direct attack towards discriminated communities. Their members become subjects of harassment, persecution, displacement, vandalism and acts of physical violence. From there it is now close to extermination, i.e. the elimination of individual members of the group, and then even the entire different community. This mentioned "scale of public rejection" introduced by P. Sztompka shows how dangerous for the perception of different groups stereotypes are, the example of which is Holocaust carried out by the Third Reich authorities (Sztompka 2002: 301-303).

\section{PSYCHOLOGICAL APPROACH TO THE STEREOTYPE}

A significant contribution of psychology into the issue of stereotyping is an individual approach to stereotypes, indicating that they can exist in individual people's minds irrespectively of whether they are, and to what extent, shared by others (Kofta, Jasińska-Kania 2001: XI-XV). Therefore they are treated as 
elements of mutual culture (a sociological trend), but also as components of a person's individual, psychological 'equipment', determining to a substantial degree what meaning does this person assign to other people's actions. In accordance with this approach, stereotypes are in a close relation to motivation processes and emotions, the evidence of which can be found in the dependency that the sense of low self-esteem fosters the tendency of a negative perception of others (Olszyk 2013: 35).

Psychologists' scientific research in the context of stereotypization resulted in the creation of two trends: a cognitive trend, and a psychodynamic one. A cognitive approach came into view in the end of the sixties of the $20^{\text {th }}$ century, and today it is the dominant approach. The main element of this approach is an argument that stereotypes are not only beliefs regarding the social reality, but also cognitive tools, influencing the processes of attention, memorizing pieces of information and retrieving them from memory, the processes of the interpretation of other people's behaviour and drawing conclusions about characterological outlines and attitudes lying at the basis of such behaviour (Kofta, Jasińska-Kania 2001: XIII). Therefore, they constitute mental representations relating to social categories, introducing certain order in the perception of social environment and enabling to select, from the excess of complex information, these pieces of information which are the most important for relations between groups.

In research on stereotypes, the psychodynamic approach came into view at the point when it became clear that the very process of socialization, learning the social roles, does not sufficiently explain the fact that people brought up in the same culture differ in stereotypes held. The purely psychodynamic approach highlights the mechanisms of maintaining the positive self-identification as the main function of stereotypes. The approach emphasizes the role of motivation processes, in which stereotypes meet a person's mental needs, such as a positive self-esteem and the reduction of feelings of inferiority (Adorno et al. 1950: 51).

\section{THE STEREOTYPE IN LINGUISTIC RESEARCH}

Comprehensive research on stereotypes is also carried out by linguists, who focus mostly on their communicative functions. The tool of these functions is language, as one of features of a community, being the basis for understanding its tradition 
(Quasthoff 1998: 11-30). Stereotypes thus enable communication within a given cultural community, provide a specific code allowing to understand the meaning of a message regarding relations between groups, included in literature, painting, or film, but also create certain barriers in intercultural communication. From the linguistic point of view, stereotypes are considered to be a specific category of culture patterns, and the research on them focus on the reconstruction and interpretation of sources, as linguistics only have the possibility to look into long-lasting, traditional stereotypes which permanently entered the language, but which are not fully recognized at times. This is through language that stereotypes are introduced into the social circulation (Kurcz 1994: 189), therefore language is their carrier and transmitter. Consequently, stereotypes have verbal nature, they are expressed, preserved in a language, and linguistically transmitted (Chlewiński 1992: 12; Schaff 1981: 68).

The above attempted analysis of the stereotype from the sociological, psychological and linguistic point of view indicates that these views are complementary. Only after taking all of them into account, the true nature of the analyzed phenomena can be seen. Talking about the stereotype one should remember that it is a certain social fact (Kofta, Jasińska-Kania 2001: XXI) - a part of a community culture, a collective system of assumptions on the nature of the social world, accepted by certain groups about other groups, and also a psychological fact - a belief placed in the system of a specific individual's judgements about the world, associated with the individual's emotions and self-image, something which facilitates a person's orientation in the social world. A stereotype is also specific lingual formation, which is verbalized precisely through language, and the language is responsible for the introduction of a stereotype into the social circulation.

\section{THE ROLE OF STEREOTYPE IN THE POLITICAL STRUGGLE}

Stereotypes penetrating wide social circles via media, as already mentioned, influence the development of an opinion about the own group and attitudes towards other groups as well. The evaluation, schematic, tendentiousness, emotionalism and tendency to generalization make an effective propaganda tool from stereotypes in social and economic life, and first of all in political struggle. Contemporary interest in the enemy stereotyping results from the fact that the rhetoric of hate, enemy discourse, became in a great measure the language of 
contemporary authority, not only totalitarian or authoritarian, but also of elites in democratic systems.

Propaganda activities, using stereotypes in the political life, motivated by "the defence of public interest", the counteraction of the loss of economic sovereignty, the loss of religious and cultural identity, manifest themselves mainly in discrediting political enemies. Among factors affecting the fact that a given message may become a beginning of a new stereotype or may consolidate it (Młyniec 1997: 211), there are mainly: a degree of media credibility in the society, a transmission technique, emotional popularity of contents, transmission time and place, knowledge of culture, mentality and the past of people to which the message is directed. These factors' coexistence usually causes that propaganda treatments are effective. The scope of "rational crux" of stereotypes is also significant, i.e. the truth of facts being the basis of their genesis, as well as an intellectual factor. Higher education level increases criticism of incoming information and the need of specific facts being presented (Młyniec 1997: 213).

In fact, in all systems stereotypes are used in a political propaganda ${ }^{1}$. However, a system in which negative stereotypes are exposed, while simultaneously blocking the propagation of positive stereotypes, is usually closer to a totalitarian system. The exposure of negative stereotypes is aimed at shifting human attitudes towards sharp, simplified evaluations and judgements. They can be formed by a partly real threat from - allocated in the society awareness - groups, but they can also be artificially generated by ideology and propaganda (Olszyk 2013: 16). Stereotypes, as important social facts in the political life, are used not only to build and maintain the community of views functioning in the elite or political class environment, but are also used to exaggerate divisions between privileged and discriminated groups.

Researches showed that the closeness of presidential or parliamentary elections results in the activation of the majority of stereotypes in combination with searching for information about the origin of people aspiring to the authority

${ }^{1}$ A political propaganda is intentional, carried out by persuasion and manipulation methods, emotional-intellectual impact on the awareness of individuals and social groups in order to modify and possibly change their attitudes and political behaviour, according to the interests of political entities and political authority. Therefore, it consists of a mass dissemination by determined means, symbols, slogans, ideas, views, and political doctrines as well as sociopolitical theories. It is also the platform of political fight between the entities seeking to induce real society support, while simultaneously discrediting their political opponents (Sobkowiak 1999: 459; Kuśnierski, Frydrychowicz 1980: 42). 
(Grzesiak-Feldman 2006: 20). During election campaigns, being a kind of arena of political rivalry to fight for the support of voters, stereotypes enable to show the enemy in a negative light, to charge them with responsibility for all crises and failures. Therefore, they constitute an excellent tool of persuasion and manipulation. Aggression, hate and hostility appear very often during election campaigns, they are almost a permanent, repetitive element of electoral propaganda. It is associated with the appearance of enemy figures, with which one must fight for the deficit welfare, which is the authority.

\section{AN ENEMY OR AN OPPONENT}

An essential element of "the enemy stereotype" term is the enemy/opponent concept. Dictionary definitions describe an enemy as a person or group of people, hostilely disposed towards somebody, who fight against someone/ something and act destructively to cause someone harm. An enemy becomes the one who raises distrust, from whom dislike or hostility are sensed towards "us", "our" interests, or who ignores them and accomplishes his/her objectives by "our" cost (Universal Dictionary 2003: 512). The enemy's entity is perceived as a real or imaginary threat to achieve objectives by other groups, and it is accompanied by various aggressive behaviours, anger, frustration, sometimes even hate.

Important - from the point of view of these deliberations - is to distinguish the concept of "the enemy" from "the opponent". The appearance of "opponent" category in rivalry situation is a natural phenomenon and constitutes an essential part of the political life. An opponent is a person or a group which, by virtue of their views and a place taken on the political scene, becomes a natural competitor of another group, representing other values and worldview in the struggle for socially desirable goods (e.g. authority). Such an opponent, as already mentioned, is an entity (person, group, other state, etc.) which ranks as a rival by virtue of their views, revealed values other than presented by remaining entities involved in rivalry. With an opponent there is a discussion, whereas with an enemy one only fights, rejecting dialogue, compromise, agreement. An opponent is a partner who tries to win in accordance with rules. An opponent can become an enemy in the situation of exacerbated rivalry, when his/her actions are driven by negative emotions, malice, aggression, the lack of respect of existing law and fair play principles being in force during rivalry. 
An enemy's entity is perceived as a real or imaginary threat to achieve other groups' objectives, accompanied by diverse aggressive behaviours, anger, frustration, sometimes even hate. The enemy is a stranger, who created in the past, creates or may potentially create a threat to "our" groups, he/she is somebody devoid of all arguments, who in the public life should be disavowed, neutralized or even destroyed with all available means. Application of this category is used to discourse identity, it enables to unite social groups around the state authority, to sanction and to elevate governing elites. Fighting with an enemy entity one does not count costs, using even those means which are not in accordance with the principles of fair competition. It is hard to conduct precise semantic distinction between the enemy and the opponent category. However, it could be stated that the difference is in the degree of reluctance, so the opponent would be a tempered version of an enemy (Głowiński 2009). While one must fight with the enemy, with the opponent - in certain circumstances and after certain assumptions - it is possible to talk, thus there is a certain common ground for agreement. Therefore, every enemy is an opponent, but not every opponent is an enemy (Olszyk 2013: 60).

\section{HOSTILITY IN POLITICS}

The enemy concept is very wide and it concretizes always in a determined political situation. In history, individuals, social organizations, social relations, subjects and natural phenomena, as well as creations of human imagination were presented as enemies. The choice depends on historical conditions, tradition, theoretical and program assumptions of a given political authority and immediate political needs. For democrats, the dictators and absolute monarchs are enemies, for atheists - all deities, egalitarians fight the oligarchy, communists are against private property and classes. The enemy is presented as being deprived of rightness and, at least, morally suspicious. Meanwhile, it is possible to become an enemy when a truth is proclaimed, as far as one infringes someone's interests (Karolczuk 2010: 11-12). In political activity, for many years the racial, ethnic and religious criteria were main factors which were taken into consideration when describing the enemy. Although politicians generally avoid them in official speeches, they function in a colloquial awareness and appear in specific situations of social tensions, where they are smuggled towards citizens in a camouflaged way. Nowadays, along with the society atomization, an enemy concept has been 
intensified, it is possible to be an enemy on the political, economic, racial, or cultural level, etc. - the more reasons to make an enemy from somebody, the better - owing to that it is possible to gather around oneself effectively undecided social layers.

Considering the enemy issue from the historical perspective it is necessary to point out that the concept was not explicit in different ages, for different researchers and participants in the political life as well as for various social forces. States often searched for outside enemies in order to facilitate paralyzing all inner enemies. Not all enemy concepts should be regarded as justified, both for political and moral reasons. In ancient Greece, through the procedure of ostracism the "enemies of democracy" were exiled. Persians' enemies of Greeks were portrayed in the art in the shape of various monsters. In ancient Sparta, enemies were sought in unapologetic Helots ${ }^{2}$, for which young Spartans organized annual bloody hunts. In ancient Rome, leaders drew up lists of inner enemies which were regarded as dangerous and were allocated to liquidation - outside enemies were described as barbarians. In Middle Ages, heretics and witches personified enemies, and they were accused of demolishing feudal social order (Karolczuk 2010: 157).

In the beginning of the development of capitalism, Niccolò Machiavelli sought the enemy in everyone who threatened, in his opinion, the perfect political system, i.e. the republic. He assumed that all people are evil, and they will assuredly prove to be such if only they will have an opportunity, and the ruler will not stop them. Therefore, the ruler's goal is to protect the state against enemies and in order to achieve this objective, the ruler can have at his disposal all available measures for the elimination of enemies threatening the republic. Thomas Hobbes (2005) views are also noteworthy. He propagated a natural genesis of the enemy, he believed that the fight between people was a natural state which accompanied mankind from the very beginning. He assumed that a dominant feature of human nature is the aspiration to accomplish egotistical interests, tendency to aggression and constant battle with others ("a man is a wolf to his fellow man"). Therefore, everyone is an enemy for everyone and it is a natural situation, resulting from the fact that a man has unrestricted freedom

2 It was one of Sparta's society layers, consisting of conquered land residents, without any laws, and being a basic workforce of the Spartan village. 
and no authority limiting him from the outside. The only way to stop the war of everyone with everyone is to relinquish the individual freedom by the conclusion of social agreement (Olszyk 2013: 54).

However, an English philosopher, a political scientist and economist John Locke (1992: 167) believed that personal interests did not determine whether somebody was an enemy, but a violation of the laws of nature did. Therefore, the enemy is the one who breaks the laws of nature, who tries to deprive another man of freedom or subject him to absolute authority; it is somebody who steals private property, applies unjustified authority on an individual, rejects or explicitly distorts the justice as well as conspicuously uses the law to protect people committing rapes or doing harm. Moreover, the enemy is the one who tolerates or protects other enemies, and the worst enemy is the one who stands against the political organization of civil society.

In the $20^{\text {th }}$ century, the enemy and friend concept in the politics was presented in detail by a German political scientist Carl Schmitt (1888-1985) ${ }^{3}$. Schmitt saw the nature of politics in the unceasing division of society into friends and enemies by authority, into "own" and "other". The arousal of fear, hate and mutual suspicion in the society among various social and political environments was a consequence of such a belief, as well as an aspiration to the gradual limitation of freedoms and liberties of groups perceived hostilely on the way to their total elimination. According to him, seeking for the enemy and its definition constituted the aim and meaning of political activity. Moreover, C. Schmitt paid attention to a substantial role of using myths in the political struggle, peculiarly in the creation of a negative image of own enemies (Dobrosielski 2007: 108-109). A political enemy, in Schmitt's view, does not have to be morally bad, does not have to constitute an economic competition; the enemy is fighting - or at least ready to fight - group of people which stands in the way of other, similarly organized group. In case that currently there is no threatening group, if that will be beneficial for the political situation, one can and even should make efforts towards the "creation" of such enemy. According to Schmitt, it is possible

3 Specialist in the field of state and international law, social philosopher and theoretician of the law, theoretician of the authoritarian state, co-originator of so-called political theology. His views turned out to be highly useful for Nazis of the Third Reich, because the enemy ideology became one of the most essential elements of Nazism. It was used to solve social matters, as well as an implementation of politics conquests. His enemy conception was presented in their works (Schmitt 2000, 2008). 
to announce the enemy in every matter, and its concept is used to discourse identity, it enables to unite social groups around the state authority, to sanction and to elevate governing elites. It is only necessary to take advantage of existing racial, religious, worldview, economic, ethnic opposites or others in order to use them as a basis to transform into political opposition as well as to divide people into friends and enemies (Karolczuk 2010: 78-81). A war, although it is not an aim and meaning of the politics, constitutes a natural consequence of real differences as well as proves determination and consequent will to fight the enemy. Therefore, the war is an ultimate form of hostility fulfilment.

All ideologies created as a basis for a totalitarian system referred to demagogic promises of a bright future. The achievement of this aim was, in fact, impossible; hence there was also a need to indicate "the guilty" of delays in its implementation. The enemy category was suitable for this treatment perfectly, since the authority, as already recalled, could arbitrarily appoint successive groups bearing responsibility for failures, and hence strengthen bases for its legitimization. Moreover, the indication of threats from the enemy part increased the level of fear in the society, and in consequence a support for the strong authority, which took responsibility for solving problems and ensuring order, broadened. Pointing successive individuals guilty for the failures of the state, and the fact that these individuals were at the same time its citizens, was for some highly satisfactory, as it released them from a sense of responsibility for their fate and made them feel comfortably, passing the burden of responsibility to others. Therefore, the totalitarian propaganda was particularly attractive for these social groups who felt ruled out and helpless (Olszyk 2013: 57).

Research on the enemy concept, also in the context of totalitarianism, was conducted by Hannah Arendt, who is an author of "the objective enemy" concept. The objective enemy is not an individual or group whose dangerous thoughts should be provoked or whose past justifies suspicions, but an individual who is "a carrier of tendency" (Arendt 2008: 180-181). Two structures are located in the enemy figure: a figure of "the real enemy", that is the one who indeed proclaims views contrary with those officially regarded as being in force (or who takes such actions), and a figure of "the objective enemy", i.e. individuals or groups recognized by the authority as harmful, while this harmfulness has perhaps a potential nature. Therefore, the authority's aim is to prove this possible harmfulness and convince others to their arguments. The concept of "the objective enemy" focuses on "objective" indication of "objective" and "potential" harmfulness of an individual or social group determined as such. One does 
not have to prove guilt of such enemy, it is enough to regard the stigmatized individual as potentially able to commit an act incompatible with the authority expectations (Jakubowska-Branicka 2008: 241). Therefore, the objective enemy concept does not include the objective element, real guilt. It constantly insults a second man until everyone knows that this is an enemy so they could destroy it in a self-defence.

The "objective enemy" concept is rooted in a totalitarian vision of the world expressed in totalitarian ideologies, dogmatic by design, which in spite of their content always rely on confronting good with evil; in addition, the good is defined by compliance with propagated ideology, and the evil by any criticism of this ideology (Jakubowska-Branicka 2008: 242).

However, in the Marxist theory, a concept of "enemy of the class" and "enemy of the people" functioned as terms describing a man belonging to a class antagonistic to proletariat, and acting against it. According to this theory, an enemy is a result of features projection and elite aspirations. In other words, the enemy image is an image of oneself, one's own aspirations and dreams. Therefore, everyone who opposed the existing authority became a class enemy (in reality or in imaginary way), thus constituting a threat to its function. A simple consequence of the creation of an enemy to be the main propaganda figure was radical militarization of its language - the enemy runs psychological war, therefore it is necessary to counteract all its actions, which seem to have peaceful nature (Głowiński 1991: 65).

A literary theorist, and an author of numerous works devoted to language in times of the People's Republic of Poland, Michał Głowiński claims that an enemy figure is a basis of the entire communist propaganda. Generally speaking, without an enemy figure there would not be a propaganda communist discourse. An enemy determines a way to perceive the world, as well as ways of thinking and speaking. When there are no real enemies or when they are not threatening or affecting reality, it is necessary to create them artificially, to invent them. Without an enemy figure there is no newspeak ${ }^{4}$. When the enemy figure descends

4 Newspeak is a term created by George Orwell in order to determine the official language of Oceania - totalitarian state from the anti-utopian 1984 novel. A new language was drawn up as the tool to control thoughts of citizens, because from one side it provided a means to express worldview in accordance with the official ideology of totalitarian state, on the other it prevented to formulate any independent thoughts, and consequently it caused an uncritical view at sociopolitical reality surrounding citizens. Therefore, newspeak is a language of political propaganda, which in advance makes impossible for self-reliance 
into a further perspective, or even disappears, the newspeak stops functioning (Głowiński 1993: 358-359). Without an enemy it simply cannot exist. The enemy reality does not have any meaning. On the contrary, it is generally an imaginary figure, with greater or smaller awareness, intentionally created.

Today, in political activity considered in the categories of fight, the figure of the enemy is still present. Such a fundamental, but not only, enemy is a direct competitor in elections; it is everyone who in a realistic or a potential way may threaten the achievement of the political objective. Therefore, all political orientations, these so far exercising authority and those which are in opposition, become real or potential enemies; also national minorities, immigrants, international finance, foreign capital, national and foreign institutions, other nations, states, groups of states (e.g. the European Union), other cultures, worldviews, faith, races or sexual orientations, can be perceived as entities recognized as hostile (Olszyk 2013: 60).

An enemy figure in political rhetoric, especially election rhetoric, is usually drawn up clearly and assumes a specific shape, because the leader wants to prove that he/she is able to identify not only the evil, but also its perpetrator, as well as to pass a feeling that a given party distinguishes from other political offers, and therefore it is worthwhile to give it a vote. Symbolic stigmatisation of the enemy is supposed to integrate the leader's own party ranks and gather negative sentiments of his/her own electorate, focusing them on the aim of the attack. Moreover, presenting political opponent as "the enemy" is aimed to trigger in voters a sense of threat, and as it is known, the aggression, hostility, and fear are effective stimulants for action. Hate, and the fear of danger are very strong incentives used on a wide scale in the election propaganda (Kołodziejczyk 1993: 240).

and citizen's freedom thinking, assumes false and lie, as well as the existence of only legitimate reason, crossing the dialogue out. Newspeak was created as a tool to enslave minds and thus was used by totalitarian states. With the help of newspeak propaganda machines created a new reality, in which the official ideology permeated every life aspect and there was no exception from it. M. Głowiński is an author of in-depth newspeak analysis, who listed the following newspeak characteristics: univalentness, coexisting of slogans and stereotypes, magic of the word, arbitrariness (Orwell 2010; Głowiński 1991). 


\section{DEFINITION AND THE STAGES OF THE ENEMY STEREOTYPE DEVELOPMENT}

Theoretical analysis of the issues related to the "stereotype" and "hostility" permits to form a separate term, "enemy stereotype". It is therefore concluded that an enemy stereotype is a schematic, strongly coloured emotionally, negative image of an individual, groups, institutions, states, etc., perceived as a threat for existence or the achievement of other entities' objectives. The enemy stereotype is most often a controlled phenomenon (it constitutes a result of persuasion and manipulation), aimed to present an enemy in the worst light in order to eliminate them from the game. Measures which support creating a negative, stereotyped image of the enemy may be: negative (malicious) criticism, labelling (naming individuals, groups or social categories, so-called "sticking small labels"), and polarization (creating ambiguous opposition "we" - "they", which enables to reduce the value system to the opposites "black" - "white", what in turn creates a division into "our" - good, positive, and "their/other" - bad, negative, additionally reinforced by valuation and aggressive language.

Enemy rhetoric and rhetoric of hate become largely a contemporary authority language, also in democracies states. Societies of Central and Eastern Europe, including the Polish society, abandoned the socialism as an ideology delineating the system slowly and in stages. Principles characteristic for the market economy and a democratic political order took place of socialist principles. Mental patterns, historical experience and habits formed in the previous period did not lead to rapid changes in the social awareness (Marody 1991: 256). Long-term social and political crises contributed to frustration and seeking for new prescriptions; the resistance of tradition against modernization took place, and also the victory of memory over thoughts about the future. The sense of social risks, characteristic for the Polish society, had its source in the lack of transparency of authority's actions on the everyday activity level. Lack of a direct contact among groups, restricted information and frustration resulting from an economic and political situation undoubtedly contribute to distance between these groups and the perception of them in terms of threat categories (Sosnowski, Walkowiak 1979: 209). Enemy discourse, present in the development of the enemy stereotype, constitutes rhetoric of absolute rationale, which means that good arguments are always provided by "our" side, "we" are entitled to them unquestioningly, and malice as well as aggression become a dominant factor in statements. Fully absolutized opposites are applied, the world is black and white, and there are 
no indirect stages. "Our" arguments comprehend everything that we regard as good, whereas "they" are deprived of all rations. Those rations have different national, political, religious grounds, and cannot be a subject of comments or reflection, they are only obvious. The rhetoric of exclusive and absolute rationale precludes any discussion, not only with those which are on the other side, but also amongst own supporters.

In order to determine the content of the enemy stereotype, as a universal language category used in political activity, it is necessary to focus attention on common elements used in different situations and circumstances for the structure of such stereotypes.

Creating an enemy stereotype is a consequence of dichotomous worldview, the world is perceived in terms of "own" - "other". Enemy stereotype arises and develops on the basis of the stereotype of "other", which is complemented by an auto-stereotype of the own group (Sobczak 2005: 97). Therefore, the stereotype of "other" does not say much about those who are its subject, but provides relevant information about the group which developed the specific stereotype of "other" (Mirga 1984: 64-65). Formulation of the definition of "other" is the essential condition for building the group's own awareness and auto-definition. Teresa Hołówka (1986: 169) recognizes it as follows: "[...] in a universal uniformity only others - a group located on a peripheral of our world, which for unknown reasons can see, hear, feel, thinks and behaves differently than we makes a breach. This dissimilarity is an intellectual and moral defect and constitutes a source of evil'. Stereotype features are developed on the basis of the impact of group values in "own"-"other" relation. This dichotomy reveals a Manichaean world vision reflected in language, which is aimed to assign social phenomena names to the category of good or evil. Speech in this language (newspeak) is treated as a tool which determines thinking and behaviour of individuals and groups. The adoption of this Manichaean vision of reality as real will probably result in a belief that "they", exactly by virtue of placement in a negative perspective, are worse than "us". The next step is to recognize the category of "them" as an enemy. The important fact is that "own" and "other" categories are not created by an individual itself, but by a group or groups of which this individual is a member, and that "own" and "other" is experienced in the process of perception of signs of the judged individual's external reality. These are among others: language, attire, ritual, ceremony, speech, as well as public activity revealing different or identical objectives, values and cultural patterns (Hołówka 1986: 58). Another stage consists of the generalization of the enemy figure, which is applied to the enemy 
stereotype description, and consequently the collective responsibility concept is regarded as right (Jakubowska-Branicka 2008: 248). However, it should be noted that the stereotype of "other" is not always negative. If the relations of the group which forms a stereotype with the group it evaluates are more distant and weaker, the probability that positive stereotype will be formed is greater. However, if connections between these groups are closer and deeper, the probability of a negative stereotype increases.

The stereotype of "other" does not have to be, although most often is, a negative stereotype showing negative features. However, the enemy stereotype is always a negative one. An enemy is a stranger, who creates or potentially may create a threat to the group that develops a given stereotype.

Among factors that form the enemy stereotype an important role seems to be played by elements which are characterized by the relations of enemy to faith or specific religion. Therefore, these expressions are an essential part of the enemy stereotype: heathen, atheist, mason, heretic, on the other hand: clericalist, papist, Islamist. A lot of elements also refer to the intellectual potential of the enemy. These include, among others: craftiness, forethought, economy, wisdom, as well as laziness, vindictiveness, nastiness, mismanagement. Moreover, external features have great importance: haughtiness, dirt, garrulousness, being phlegmatic, meanness. Quite often the mystery of the enemy is emphasized in stereotype context, the lack of clear information as to their appropriate objectives and intention. Hence, such expressions also appear: hooded supporter, illiterate enquirer, and troublemaker. It is associated with the conspiratorial vision of the world of groups which create the stereotype. One who does not share their ideas or who is on the opposite side is no longer only an enemy, but - further - is the one who incessantly plots, creates mysterious arrangements, acts to the detriment of Nation, State, Church, and above all - against Polish interests. Among the enemy stereotype elements many are ordinary insults and offensive expressions, such as: rascal, liar, minion, traitor, agent, thug, puppet, swindler, madman, idiot, etc. Often the very definition of racial, sexual, political worldview or national affiliation, already coloured negatively in an emotional way, becomes an essential part of the enemy stereotype, e.g.: Bolshevik, nigger, nip, fag, commie, cacique, anti-Semite, Jew, Fritz, Rusky, but also Polack, Czesky, Pom, or Yankee. These nicknames are aimed to disqualify an enemy in the public and international opinion (Olszyk 2013: 64).

It is crucial not to forget that an important part of the process of creation of the enemy stereotype is an appeal to fear, using anxiety in order to terrorize the 
society, and thereby enforce certain behaviour. Canalization of fear and social frustration is carried out by aggression contributed to weaker ones, e.g. to members of minority groups included in other nationalities, becoming "a scapegoat". Strangeness arouses fear, and this in turn causes negative evaluation in some measure by design, without looking closer at "others". That anxiety excludes rational action and supports reactions based on "emotional automatisms", because it redirects human thoughts from a careful analysis of a given issue towards plans of release from it, what as a result causes greater submissiveness (Pratkanis, Aronson 2003: 182-189). Therefore, fear is a huge psychological power, which conducts human thoughts and energy towards the elimination of the threat, making an effective tool of manipulation in the social and economic life, but first of all in the political struggle.

The creation of a relatively precise definition of the enemy stereotype, the indication of the stages of its formation and the presentation of its role in political struggle is, in the author's opinion, very important for researchers in various fields of knowledge, especially for those who analyze political (election) discourse. It describes a given society, its anxieties, traditions, mentality, and ways of reaction in critical situations. It is also a precious source for the recognition of psychosocial basis of many political phenomena in the field of international relations as well, playing an important role in diagnoses and political studies.

\section{REFERENCES:}

Adorno T. et al. (1950). The Authoritarian Personality. New York: Harper \& Bros.

Arendt H. (2008). Korzenie totalitaryzmu. Vol. 2. Warszawa: Wydawnictwa Akademickie i Profesjonalne.

Bar-Tal D. et al. (1989). Stereotyping and Prejudice. Changing Conceptions. New York: Springer-Verlag.

Bar-Tal D., Teichman Y. (2005). Stereotypes and Prejudice in Conflict. Cambridge: Cambridge University Press.

Bartmiński J.(1985). Stereotyp jako przedmiot lingwistyki. [in:] Z Problemów Frazeologii Polskiej i Słowiańskiej. Vol. 3. M. Basaj (ed.), Wrocław: Zakład Narodowy im. Ossolińskich.

Chlewiński Z. (1992). Stereotypy, struktura, funkcja, geneza. Analiza interdyscyplinarna. [in:] Stereotypy i uprzedzenia. Vol. 1. Z. Chlewiński, I. Kurcz (eds.). Warszawa: Wydawnictwo Instytutu Psychologii PAN.

Dobrosielski M. (2007). Powyborcze refleksje. „Przegląd Socjalistyczny” 6.

Dovidio J.F., Gaertner S.L. (eds.) (1986). Prejudice, Discrimination, and Racism. Orlando: Academic Press. 
Dubisz S. (ed.) (2003). Uniwersalny słownik języka polskiego. Wydawnictwo Naukowe PWN: Warszawa.

Fiske S.T., Taylor S.E. (1991). Social Cognition. New York: McGraw-Hill.

Głowiński M. (1991). Nowomowa po polsku. Warszawa: PEN.

Głowiński M. (1993). Peereliada. Komentarze do słów 1976-1981. Warszawa: Państwowy Instytut Wydawniczy.

Głowiński M. (2009). Retoryka nienawiści. „Gazeta Wyborcza”. [online] http://wyborcza. pl/1,76842,7251866,Retoryka_nienawisci.html; [accessed 13.11.2009].

Gostkowski Z. (1959). Teoria stereotypu i poglądy na opinię publiczna Waltera Lippmanna. „Archiwum Historii Filozofii i Myśli Społecznej” 5.

Grzesiak-Feldman M. (2006). Tożsamościowe uwarunkowania posługiwania się stereotypami. Warszawa: Wydawnictwo Uniwersytetu Warszawskiego.

Hobbes T. (2005). Lewiatan czyli Materia, forma i władza państwa kościelnego $i$ świeckiego. Warszawa: Fundacja Aletheia.

Hołówka T. (1986). Myślenie potoczne. Heterogeniczność zdrowego rozsądku. Warszawa: Państwowy Instytut Wydawniczy.

Jakubowska-Branicka I. (2008). Znaczenie figury „wroga obiektywnego” w języku współczesnej propagandy politycznej. [in:] Mity, symbole i rytuały we współczesnej polityce. Szkice z antropologii polityki. B. Szklarski (ed.). Warszawa: Wydawnictwo Naukowe Scholar.

Jeziński M. (2007). Marketing polityczny i karnawał. Uwagi na marginesie wyborów roku 2005. [in:] Media w wyborach. Kampanie polityczne. Media w polityce. T. SasińskaKlas (ed.). Toruń: Wydawnictwo Adam Marszałek.

Karolczuk E. (2010). O wrogu. Szkice filozoficzno-historyczne. Warszawa: Instytut Wydawniczy „Książka i Prasa”.

Kofta M., Jasińska-Kania A. (2001). Wstęp. Czy możliwy jest dialog między społecznokulturowym a psychologicznym podejściem do stereotypów?. [in:] Stereotypy i uprzedzenia. Uwarunkowania psychologiczne i kulturowe. M. Kofta, A. JasińskaKania (eds.). Warszawa: Wydawnictwo Naukowe Scholar.

Kołodziejczyk E. (1993). Stereotyp w języku współczesnej polityki. [in:] Mity i stereotypy w kulturze, literaturze i języku. M. Kozłowska, E. Tierling (eds.). Szczecin: Wydawnictwo Naukowe Uniwersytetu Szczecińskiego.

Kurcz I. (1994). Zmienność i nieuchronność stereotypów. Studium na temat roli stereotypów w reprezentacji umysłowej świata społecznego. Warszawa: Wydawnictwo Instytutu Psychologii PAN.

Kurcz I., Chlewiński Z. (1992). Stereotypy, prototypy i procesy kategoryzacji. [in:] Stereotypy i uprzedzenia. Vol. 1. Z. Chlewiński, I. Kurcz (eds.). Warszawa: Wydawnictwo Instytutu Psychologii PAN.

Kuśnierski S., Frydrychowicz A. (1980). Podstawy wiedzy o propagandzie. Warszawa: Książka i Wiedza.

Lippmann W. (1922). Public Opinion. New York: Brace and Company.

Locke J. (1992). Dwa traktaty o rzadzie. Warszawa: Wydawnictwo Naukowe PWN. 
Maison D. (1997). Jak powstaja stereotypy narodowe. Warszawa: Oficyna Wydawnicza Wydziału Psychologii Uniwersytetu Warszawskiego.

Marody M. (1991). System realnego socjalizmu w jednostkach. [in:] Co nam zostało z tych lat... Społeczeństwo polskie u progu zmiany systemowej. M. Marody (ed.). Londyn: Aneks.

Mirga A. (1984). Stereotyp jako model "prawdziwego swojego" i „obcego” (Próba rekonstrukcji teoretycznej zjawiska stereotypu). „Zeszyty Naukowe Uniwersytetu Jagiellońskiego. Prace Etnograficzne"19.

Młyniec E. (1997). Teoria stereotypu. [in:] Studia z teorii polityki. Vol. 2. A.W. Jabłoński, L. Sobkowiak (eds.). Wrocław: Wydawnictwo Uniwersytetu Wrocławskiego.

Nelson T.D. (2003). Psychologia uprzedzeń. Gdańsk: Gdańskie Wydawnictwo Psychologiczne.

Olszyk S. (2013). Stereotyp wroga w walce wyborczej w Polsce (1991-2011). Toruń: Dom Wydawniczy DUET.

Orwell G. (2010). Rok 1984. Warszawa: Warszawskie Wydawnictwo Literackie Muza.

Pratkanis A., Aronson E. (2003). Wiek propagandy. Warszawa: Wydawnictwo Naukowe PWN.

Quasthoff U. (1998). Etnocentryczne przetwarzanie informacji. Ambiwalencja funkcji stereotypów w komunikacji międzykulturowej. [in:] Stereotyp jako przedmiot lingwistyki. Teoria, metodologia, analizy empiryczne. Vol. 12. Wrocław: Towarzystwo Przyjaciół Polonistyki Wrocławskiej.

Reber A.R. (2000). Słownik psychologii. Warszawa: Wydawnictwo Naukowe Scholar.

Sasińska-Klas T. (2010). Stereotypy i ich odzwierciedlenie w opinii publicznej. [in:] Mity $i$ stereotypy w polityce. Przeszłość i teraźniejszość. A. Kasińska-Metryka, M. Gołoś (eds.). Toruń: Wydawnictwo Adam Marszałek.

Schaff A. (1981). Stereotypy a działanie ludzkie. Warszawa: Książka i Wiedza.

Schmitt C. (2000). Teologia polityczna i inne pisma. Kraków-Warszawa: Znak, Fundacja im. Stefana Batorego.

Schmitt C. (2008). Lewiatan w teorii państwa Thomasa Hobbesa. Sens i niepowodzenie politycznego symbolu. Warszawa: Prószyński i S-ka.

Sobczak J. (2005). Stereotyp wroga. [in:] Obcy-Sąiedzi-Niechciani partnerzy?. K. Glass, Z. Puślecki, B. Serloth (eds.). Poznań: Instytut Nauk Politycznych i Dziennikarstwa. Uniwersytet Adama Mickiewicza; Toruń: Wydawnictwo Adam Marszałek.

Sobkowiak L. (1999). Propaganda polityczna. [in:] Leksykon politologii. A. Antoszewski, R. Herbut (eds.). Wrocław: Atla2.

Sosnowski J.A., Walkowiak J. (1979). Kierunki badań i rozważań nad stereotypami w polskiej socjologii. „Ruch Prawniczy, Ekonomiczny i Socjologiczny” 2.

Stangor Ch. (ed.) (2000). Stereotypes and Prejudice. Essential Readings. Philadelphia: Psychology Press.

Sztompka P. (2002). Socjologia. Analiza społeczeństwa. Kraków: Znak. Wang L.I. (2006). Discrimination by Default: How Racism Becomes Routine. New York: New York University Press. 